\title{
Recycling of Rolling Stocks
}

\author{
Rafael Favoretto Silva ${ }^{1}$ and Sakdirat Kaewunruen ${ }^{2, *}$ \\ 1 Department of Civil Engineering, Pontifical University Catholic of Goiás, Goiânia 74115070, Brazil; \\ rafaelfavoretto94@hotmail.com \\ 2 Department of Civil Engineering, School of Engineering, University of Birmingham, \\ Birmingham B15 2TT, UK \\ * Correspondence: s.kaewunruen@bham.ac.uk or sakdirat@hotmail.com; Tel.: +44-121-1414-2670
}

Academic Editor: Yu-Pin Lin

Received: 1 April 2017; Accepted: 14 May 2017; Published: 25 May 2017

\begin{abstract}
This review paper highlights feasible and practicable approaches for managing end-of-life rolling stocks. It aims to promote and enable sustainable procurement policy for rolling stocks. Firstly, it demonstrates that modern rolling stocks can potentially gain the environmental benefits since almost all of their materials used in the rolling stock manufacturing can be recycled and reused. In this study, a brief definition and concept of various train types are introduced and discussed, accompanied by some demonstrative illustrations. Then, component analyses, recovery rates and percent proportion of each material in various rolling stock assemblies have been evaluated. The estimation of material quantities that can potentially be recycled has been carried out using industry data sources. The suitable management procedures for end-of-life rail vehicles are then discussed, together with the life cycle of the key materials in which the recyclability criteria take into account the environmental risks and the best and safest approaches to deal with them. The aim of this study is to increase the awareness of the public, train manufacturers and rail industries on the benefits to the environment from rolling stock recycling, which could result in sustainable society and urban livings.
\end{abstract}

Keywords: railway; trains; rolling stocks; recycling; reuse; life cycle; environmental benefit

\section{Introduction}

This research study portrays the importance and significance of having an appropriate disposal management of the end-of-life rolling stocks. Besides the social responsibility, manufacturers and owners of rolling stocks must respect ecological aspects and ensure that necessary activities are carried out to minimize environmental impacts. When producing new rolling stocks, the manufacturers must consider the whole vehicle life cycle, including production (design, building and manufacture), use (operation and maintenance) and, finally, the end of life (vehicle disposal), which is the main point of this research. The last stage of life cycle of rolling stocks can be considered successful if it achieves the principle of the ' $3 R$ ': reduce, reuse and recycle. Considering the future environmental impacts, the procurement and design stages of new rail vehicles should consider a reduction in the amount of waste generated after the disposal of rolling stock materials. Also, the amount of the generated waste should be recycled as much as possible.

Since the amount of waste from end-of-life rolling stocks is much greater than general motor vehicles (e.g., cars, trucks, busses), the importance for the development of recycling programs becomes even higher and more prioritized [1]. For instance, the disposal of a single cargo railcar, in relation to the weight of the waste, is the same as 16-20 passenger motor vehicles (e.g., road vehicles). Furthermore, the disposal of a tram with an average length of $30 \mathrm{~m}$ results in a waste equivalent to that of $36-42$ passenger motor vehicles (e.g., 30-40 t) and a disposal of a passenger railcar also generates a considered amount 
of waste-48-57 passenger motor vehicles (e.g., 50-60 t). In the same way, a three-part electric multiple unit (EMU) can originate as much waste as 126-156 passenger motor vehicles (e.g., >160 t) [1-5].

Besides those facts mentioned above, other benefits obtained from the recycling of rail vehicles should also be taken into consideration. The other benefits related to the rail vehicles with improved environmental friendliness also include reduction of the exploitation of resources, lower costs of production of those recycled materials, or even the profits from a good product image (market premium). Hence, an effective end-of-life rail vehicle treatment is needed to resolve major global concerns such as carbon footprint (or greenhouse gas emission), energy efficiency issues, higher raw materials costs, rigorous landfill legislation and need for landfilled waste minimization, and others environmental regulations associated with the manufacturers' responsibilities, the increase in customers' environmental requirements, and the benefits and profits earned from the eco-friendly products [1,6-8]. A clear example for recyclability requirements of vehicles is the European Directive 2000/53/EC [2]. At this stage, this Directive on end-of life vehicles (ELV) aims only at making dismantling and recycling of ELVs more environmentally friendly (mostly for road industry). However, voluntary railway policy on waste management of rolling stock has not been well adopted (such as Union des Industries Ferroviaires Européennes (UNIFE) method) due to its dominant presence of stakeholders (i.e., manufacturers, sales). The dominance of rolling stock manufacturers discourages the public participation and interest, which in turn yields negative perception on conflict of interest. Based on this ground, this paper is very timely in presenting an independent critical review of recyclability of rolling stocks and highlights potential applications to enhance the effectiveness of recycling rolling stocks.

\section{Methods and Materials}

\subsection{Components Analysis}

Rolling stocks are generally classified into different groups according to their purposes and services. In European practice, the main types of trains are: passenger trains, high-speed rail and freight trains [3]. Each type is designed using different designed components and materials, as illustrated below.

\subsubsection{Passenger Trains}

A passenger train (e.g., metro, tram, light rail or urban rail vehicles) is the passenger-carrying vehicle that, usually, consists of great-length carriages and generally need to be operated at a higher speed. It can be a self-powered railcar, or a combination of one or more locomotives and one or more trailers (known as carriages) or coaches. The function of passenger trains is to provide a way of transport for passengers between the stations. They are operated in accordance with fixed schedules and have higher occupancy than other types of train. The conductor (or driver) of passenger trains has operational assistance from others crew members. Some passenger trains still may use bi-level (double deck) cars to carry more people per train [1]. Figure 1 shows an example of passenger trains and its internal components:

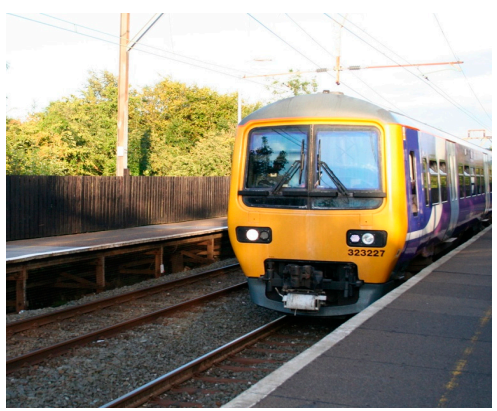

(a)

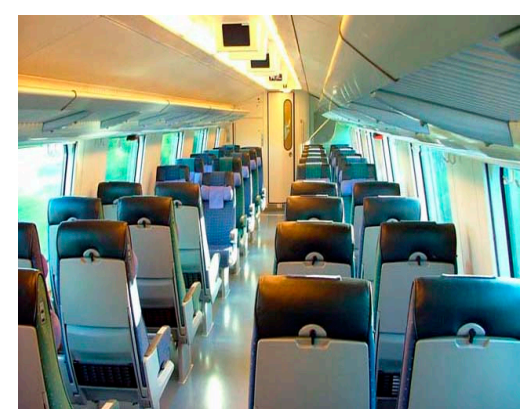

(b)

Figure 1. Passenger train (a) External part of a passenger train; (b) Interior of a passenger train. 
At the end of a vehicle life, there should be appropriate disposal management, which includes reuse, recycling, and recovery. Reuse means "any operation by which components of end-of-life rolling stock are used for the same purpose for which they were designed"; recycling is a method of "processing the waste materials for the original purpose or for other purposes, excluding processing as a means of generating energy"; and recovery applies to the concept of "processing the waste materials for the original purpose or for other purposes, including processing as a means of generating energy" $[4,5]$. In this study, the recovery rate takes into account the reusable and recyclable rates of each material.

The materials, which are derived from rail vehicles, can be divided into seven main categories: metals; glass; fluids (lubricants, oils, chemical fluids); polymers, excluding elastomers, i.e., polymer compounds, reinforced polymers; modified organic natural materials (MONM—cotton fleece, wood, leather); elastomers (rubbers); and others, such as components not built using a unique or predominant constituting material (e.g., composites) and/or made by different subparts, for instance, electronics and electrics as stated in ISO 22628 [4-14].

Trains are largely made of aluminum, steel or stainless steel, which are metals that are usually easy to recycle. The costs of steel production from materials, which have been recovered from wasted rolling stocks, are much lower compared to the iron ores production from mining sector. Although aluminum does not lose its properties after recycling, the versatile shapes and dimensions of the alloys utilized to build rail vehicles makes the process more difficult [1].

However, compared with freight trains, passenger trains are relatively difficult to recycle, due to the multiple units in particular and to a diverse and large variety of material structures. In addition, there is no current recycling technology economically efficient enough to recover composite materials, such as carbon fibers (Carbon Fiber Reinforced Polymer) or glass fiber reinforced polymer, as new technological solutions [1]. As such, the residual waste of composite materials remains considerable in practice [14-31].

The percentage data that is going to be presented in Tables 1-3 were based on drawings obtained from articles available to the public and from industry partners, as can be seen in Figures 2 and 3:
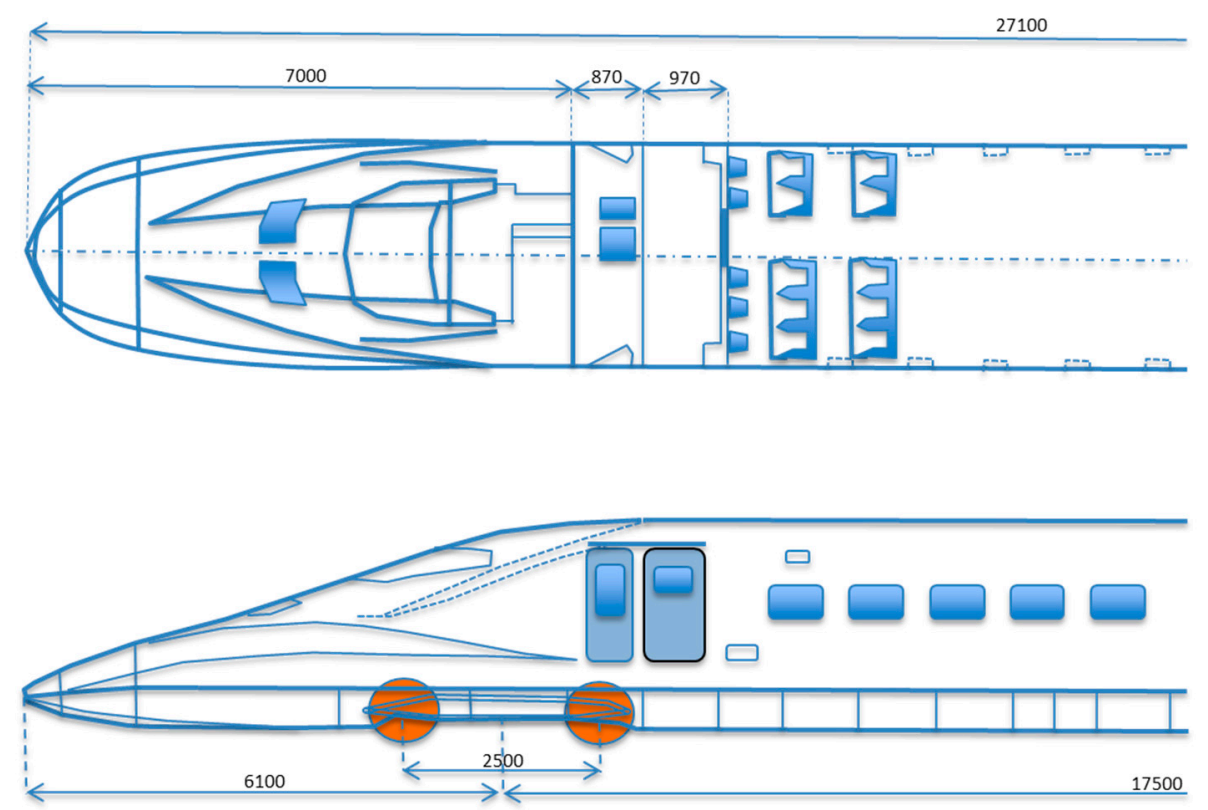

Figure 2. Major dimensions of front car of a Shinkansen passenger train (adopted from [32]). 

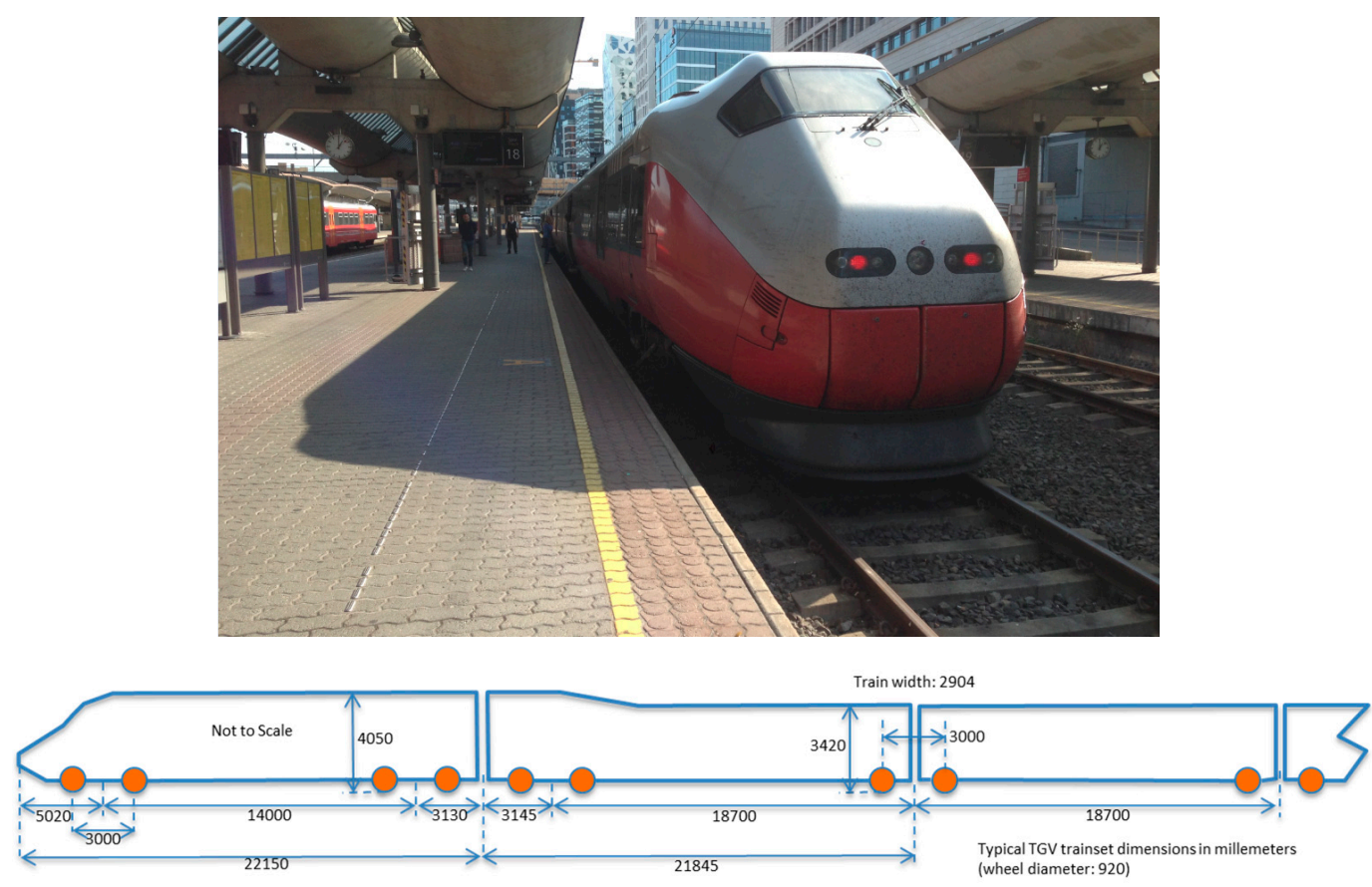

Figure 3. Key dimensions for a typical TGV trainset, in millimeters (adopted from [33]).

Table 1. Components Analysis of Passenger Train (calculated from industry sources [28-31,34,35]). The drawings and some component weights are available from the industry. Some data have been taken from the manufacturers' documents available on Union des Industries Ferroviaires Européennes (UNIFE) and train companies' websites. The furniture weights have been estimated from the drawing.

\begin{tabular}{|c|c|c|c|}
\hline \multicolumn{4}{|c|}{ Passenger Train Components } \\
\hline $\begin{array}{c}\text { Components of Train } \\
{[28-31,34,35]}\end{array}$ & Type of Material & Recovery Rate (\%) & Percentage ( $\%$ by Mass) \\
\hline Wheels & Steel R7 (carbon content $\%<0.52$ ) & $90-98$ & 13.48 \\
\hline Window & Glass & $50-100$ & 0.37 \\
\hline Roof & Aluminum/Steel & 80-95/90-98 & 4.30 \\
\hline Table & Polypropylene, polyethylene & $50-70$ & 0.22 \\
\hline Door & Aluminum/Steel & 80-95/90-98 & 1.80 \\
\hline Battery Box & $\begin{array}{l}\text { CRCA sheet and rolled sections of } \\
\text { carbon steel }\end{array}$ & $\begin{array}{l}\text { CRCA sheet and rolled sections of } \\
\text { carbon steel (90-98) }\end{array}$ & 0.09 \\
\hline Pantograph & $\begin{array}{l}\text { High-strength tubular steel or alloy } \\
\text { frame; alloy of carbon, copper }\end{array}$ & $\begin{array}{l}\text { High-strength tubular steel or } \\
\text { alloy frame (90-98); alloy of } \\
\text { carbon, copper }(60-80)\end{array}$ & 0.04 \\
\hline Condenser & $\begin{array}{l}\text { Copper, brass, aluminum, or } \\
\text { stainless steel }\end{array}$ & $\begin{array}{l}\text { Copper (60-80), brass, aluminum } \\
\text { (80-95), or stainless steel (80-90) }\end{array}$ & 0.11 \\
\hline Compressor & Aluminum & $80-95$ & 0.22 \\
\hline Coupler & Steel or composites & $90-98$ & 0.45 \\
\hline Gangway Bellows & Silicone-coated fabric & $50-70$ & 5.24 \\
\hline \multicolumn{4}{|l|}{$\begin{array}{l}\text { Electrical Auxiliary } \\
\text { Equipment }\end{array}$} \\
\hline Battery & $\begin{array}{l}\text { Polypropylene, polyethylene or } \\
\text { plastic-coated steel }\end{array}$ & $50-70$ & 0.15 \\
\hline
\end{tabular}


Table 1. Cont.

\begin{tabular}{|c|c|c|c|}
\hline \multicolumn{4}{|c|}{ Passenger Train Components } \\
\hline $\begin{array}{c}\text { Components of Train } \\
{[28-31,34,35]}\end{array}$ & Type of Material & Recovery Rate (\%) & Percentage (\% by Mass) \\
\hline Generator & Magnetic steel and copper & $\begin{array}{l}\text { Magnetic steel (90-98) and copper } \\
\qquad(60-80)\end{array}$ & 0.13 \\
\hline Alternator & Steel & $90-98$ & 0.03 \\
\hline Converter & Silicon Carbide & $50-70$ & 0.08 \\
\hline \multicolumn{4}{|l|}{ Bogie Components } \\
\hline Bogie Frame & Steel plate/cast steel & $90-98$ & 7.49 \\
\hline Bogie Transom & Steel plate/cast steel & $90-98$ & 3.37 \\
\hline Brake Cylinder & Aluminum & $80-95$ & 0.75 \\
\hline Primary Suspension Coil & Steel & $90-98$ & 0.30 \\
\hline Motor Suspension Tube & Steel & $90-98$ & 0.28 \\
\hline Gearbox & Steel & $90-98$ & 1.68 \\
\hline Motor & Steel & $90-98$ & 2.62 \\
\hline Secondary Suspension Air Bag & Textile-reinforced rubber & $50-70$ & 0.09 \\
\hline
\end{tabular}

\subsubsection{High-Speed Rail}

A high-speed rail belongs to the long-distance passenger train category as shown in Figure 4. They can run at speeds above $250 \mathrm{~km} / \mathrm{h}$ and be operated on specific and dedicated tracks prepared to support the high speeds. Japan's Shinkansen is the first successful example of a high-speed passenger rail system, which begun to operate in 1964. The fastest train, currently running on rails, is France's TGV (Train à Grande Vitesse- “TGV high speed train"). In most situations, when distances do not exceed 900 or $1000 \mathrm{~km}$, the high-speed rail travel is more time- and cost-competitive than air travel. The use of tilting technology is common nowadays to improve train stability in curves. It is an artificially dynamic form of superelevation, which allows both low and high-speed traffics to utilize the same track and produce a more comfortable ride for the passengers. This technology can be found, for instance, in Advanced Passenger Train (APT) [11-13]. Table 2 shows the component analysis of a typical high speed train.

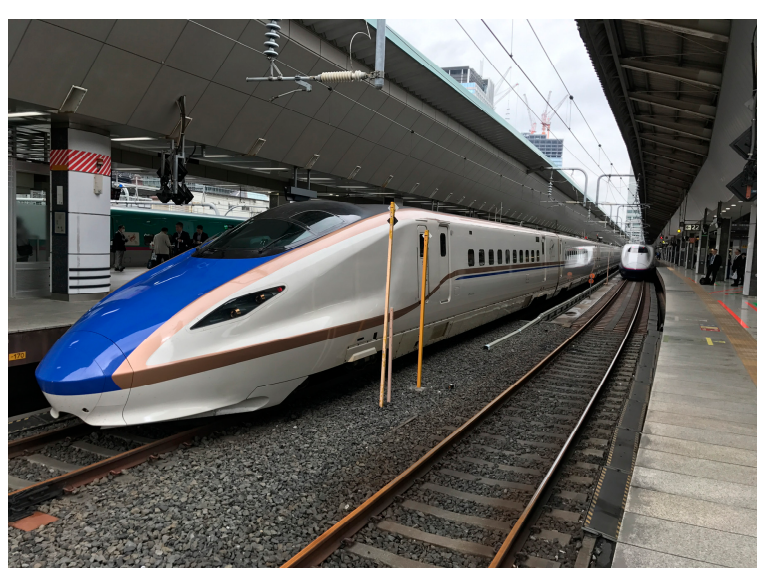

(a)

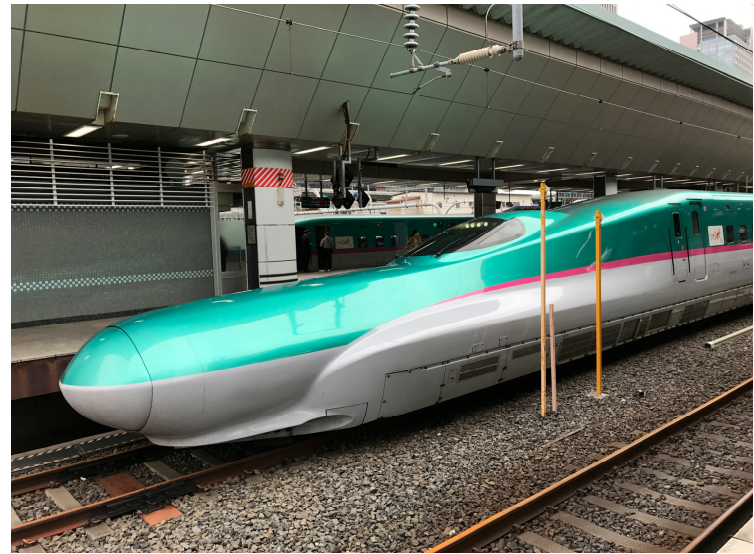

(b)

Figure 4. High-speed Rail (a) Moderate speed train; (b) High speed train. 
Table 2. Components Analysis of High-Speed Trains (calculated from industry sources [28-31,34,35]). The drawings and some component weights are available from the industry. Some data have been taken from the manufacturers' documents available on Union des Industries Ferroviaires Européennes (UNIFE) and train companies' websites. The furniture weights have been estimated from the drawing.

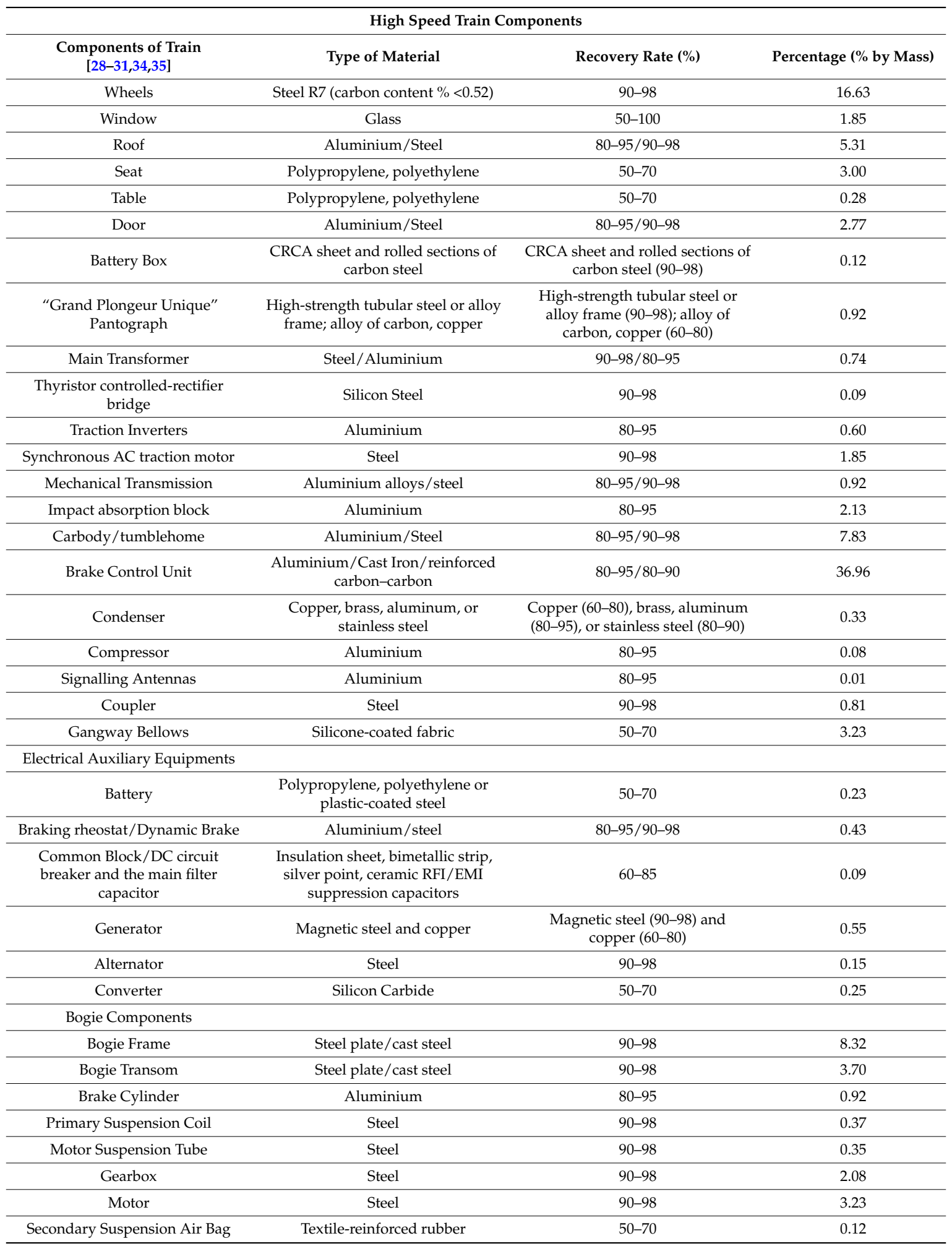




\subsubsection{Freight Trains}

A freight train contains the locomotives and the freight wagons (or freight cars) that enable logistics and transportation of materials and goods. Transporting freight by trains can generate more economical advantages and efficiency compared to transporting freight on road. The rail transportation is highly profitable when the freight is being carried in bulk and over a long distance; however, it is less appropriate for small loads and short distances. On the other hand, the lack of flexibility is the main disadvantage of rail freight. Consequently, freight trains are less required for small payloads. In fact, governments are trying to fortify transportation onto trains, due to the advantages that the rail industry would bring to regional development.

There is a range of different types of freight trains especially with many different types of wagons, which are utilized based on the type of goods or burdens they have to carry [1]. Table 3 shows the component analysis of a long-wagon freight train as shown in Figure 5. Container trains are one of the most conventional types of modern rolling stock, since containers can be lifted off from the train by cranes and loaded off onto trucks and ships. "Piggy-back" trains or rolling highway trucks are used in some countries. The trucks can also drive straight onto the train and when the final destination is reached; and they can drive off again. A similar system is utilized through the Channel Tunnel that interconnects England and France. Roadrailer is an alternative type of "intermodal-vehicle" designed to be attached to the train. Furthermore, there are many other types of wagon: well wagons or "low loader" wagons for the interchanging transportation with road vehicles, open-topped wagons for the transportation of minerals and bulk material, refrigerator cars for the transportation of food, and tankers for the transportation of gases and liquids. Nowadays, hopped wagons are used for transporting most coal and aggregates due to the convenience of enabler facility for quickly discharging and filling [1].

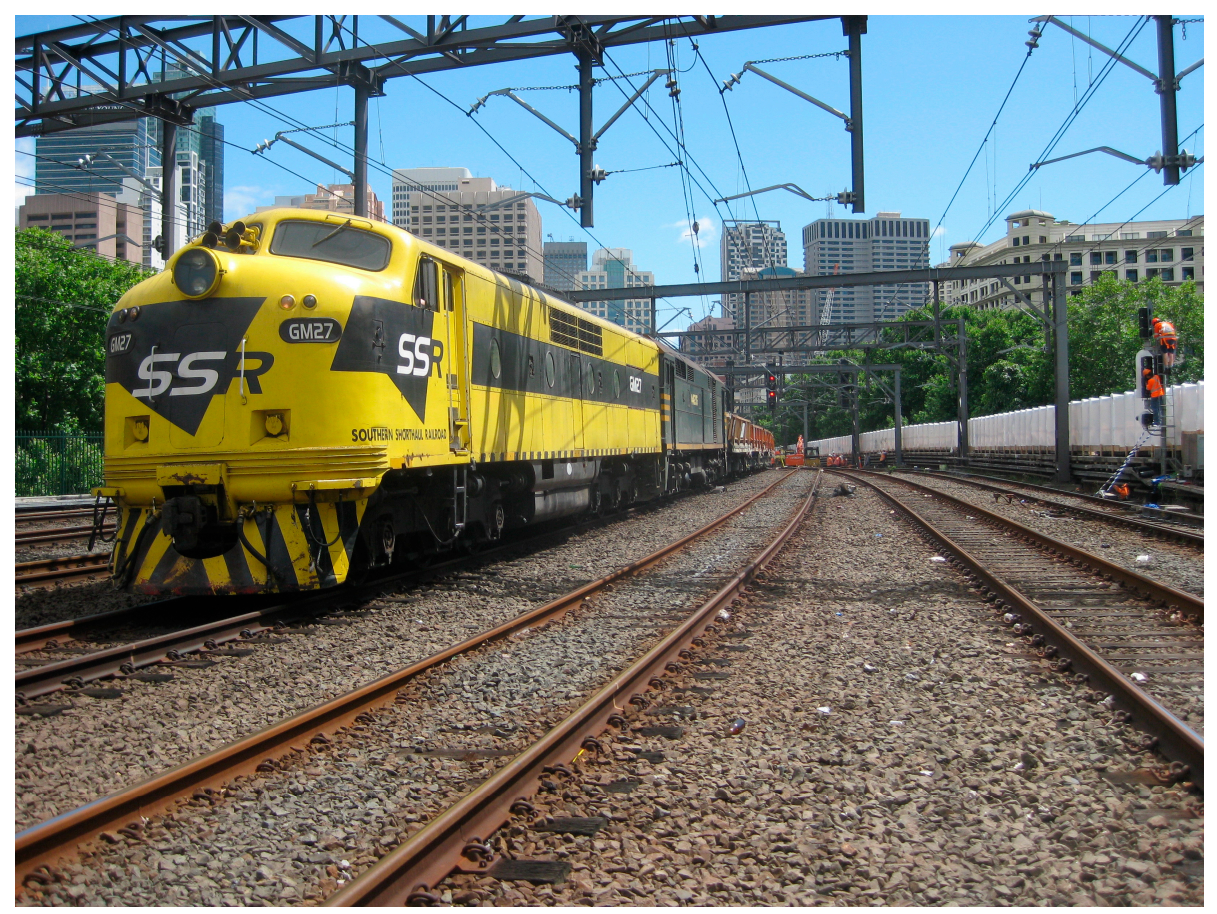

Figure 5. Freight Train.

Cargo railcars are the easiest to recycle, since around 60 to $80 \%$ of their mass is composed of cast iron and steel [1]. Freight trains are, basically, divided into two parts: the locomotive and the cargo railcars. The components analysis and their respective percentages of recycling are recorded in the table below [14-16]: 
Table 3. Components Analysis of Freight Trains (calculated from industry sources [28-31,34,35]). The drawings and some component weights are available from the industry. Some data have been taken from the parts manufacturers' documents available on Union des Industries Ferroviaires Européennes (UNIFE) and train companies' websites.

\begin{tabular}{|c|c|c|c|}
\hline \multicolumn{4}{|c|}{ Freight Train Components } \\
\hline $\begin{array}{c}\text { Components of Train } \\
{[28-31,34,35]} \\
\end{array}$ & Type of Material & Recovery Rate (\%) & Percentage ( $\%$ by Mass) \\
\hline Main Alternator & Steel & $90-98$ & 0.21 \\
\hline Air Intakes & Steel/Aluminum & 90-98/80-95 & 0.11 \\
\hline Rectifiers/Inverters & $\begin{array}{l}\text { Heavy-gauge aluminum sheet } \\
\text { metals with powder-coated or } \\
\text { anodized and stainless fittings }\end{array}$ & $80-95$ & 0.49 \\
\hline Pinion/Gear & Steel & $90-98$ & 0.56 \\
\hline Fuel Tank & Steel/Aluminum & 90-98/80-95 & 0.35 \\
\hline Air Reservoirs & Steel/Aluminum & $90-98 / 80-95$ & 0.09 \\
\hline Air Compressor & Aluminum & $80-95$ & 0.98 \\
\hline Drive Shaft & Aluminum alloys & $80-95$ & 0.60 \\
\hline Gearbox & Steel & $90-98$ & 2.32 \\
\hline Radiator and Radiator Fan & Aluminum, brass or copper cores & $\begin{array}{l}\text { Aluminum }(80-95), \text { brass or } \\
\text { copper cores }(60-80)\end{array}$ & 0.02 \\
\hline Sand Box & Cast iron & $80-90$ & 0.53 \\
\hline Battery Box & $\begin{array}{l}\text { CRCA sheet and rolled sections of } \\
\text { carbon steel }\end{array}$ & $\begin{array}{c}\text { CRCA sheet and rolled } \\
\text { sections of carbon steel (90-98) }\end{array}$ & 0.18 \\
\hline Brake Control Unit & $\begin{array}{l}\text { Aluminum/Cast Iron/reinforced } \\
\text { carbon-carbon }\end{array}$ & $80-95 / 80-90$ & 0.08 \\
\hline Brake Cylinder & Aluminum & $80-95$ & 0.34 \\
\hline Condenser & $\begin{array}{l}\text { Copper, brass, Aluminum, or } \\
\text { stainless steel }\end{array}$ & $\begin{array}{l}\text { Copper }(60-80), \text { brass, } \\
\text { Aluminum }(80-95), \text { or } \\
\text { stainless steel }(80-90)\end{array}$ & 0.42 \\
\hline
\end{tabular}

\section{Mechanisms and Current State of Practices}

\subsection{End-of-life Rail Vehicle Procedure}

The disposal of rail vehicles can be compared to the disposal process of motor vehicles. The disposal process of rolling stock is divided into five stages [1,2]:

1. Forwarding the rolling stock for recycling

The first decision that has to be made is the decommissioning of a vehicle and the place where the dismantling activities are environmentally safe and the recovery rate could potentially be high. In general, rail vehicles have a life cycle of approximately 30-40 years. The decision whether to decommission a train or not is commonly based on rolling stock damage, costs of retrofit and repairs, 
malfunctions, and operating and maintenance costs in comparison with those of new train models available on the market [1,2].

\section{Pre-treatment}

The end-of-life rolling stock can be toxic and bio-hazardous. It should then be inspected and treated as hazardous disposal [1] since the waste must guarantee safety for human health and the environment at all stages of recycling process. Accordingly, the initial treatment usually involves the removal of pollutants and hazardous waste. After being removed from the vehicle components, the operating fluids, such as brake fluids, oils and antifreeze must be stored in containers separated from each other so that they can later be forwarded to specialized recycling facilities responsible for energy recovery (oils), material recycling and residual waste management. Some of the components to be reused as spare parts might not need to be drained. Gases, fire extinguishers, greases, explosives, braking sand, batteries and catalytic capacitor must be removed totally due to environment hazards and health.

\section{Dismantling}

Parts of rolling stock that can be further recycled in the dismantling process are first removed. Initially, subcomponents and the parts that can be reused are retrieved, such as, wheel sets, bogies, bogie frames, buffers, springs, couplings, doors, brake systems and control valves. Some of them can be used directly whilst others in other rail vehicles will need additional refurbishment to regain the original operating parameters. Those parts that are going to be reused must have a special care when being removed to avoid any damage and they must pass through an inspection in order to determine the possible admittance for uses and the extent of refurbishment if needed. The rest of the elements, such as glazing, seats, wire harnesses, flooring and electronic parts are then dismantled for further material recycling. The greater the extent of the dismantling, the easier the separation of individual material fractions, and the more effective becomes the recycling process. Based on this approach, the elements of rolling stock should be dismantled as many as possible at this stage. However, since it is a costly process, its extent should be economically justified. Moreover, the dismantling process should also take into consideration the energy saving in order to enhance its effectiveness [2]. Therefore, at the design stage, the manufacturers must embrace the quality of materials, the simplification of fitting and assembly, and their classification of the materials that would really enhance future environmental and economic benefits.

After dismantling, the subcomponents and elements removed are forwarded to specialized recycling facilities, where they are sorted, separated and undergone an appropriate recycling process [17-19].

\section{Shredding}

After the dismantling process of rolling stock for material recycling, the remaining of the vehicle goes to the industrial shredder for scrapping. There are three methods to shred: shearing, tearing and fracturing. All of the three actions can be present simultaneously while a shredder is being used. However, by considering the energy saving in the dismantling process, shearing method would be the most efficient reduction action to be reinforced. Before transferring it to the shredder, the waste is compressed to reduce the space needed for the transportation, which decreases the cost of the freight. Then, the packed materials are grinded into small pieces for further treatment. The aim of the industrial shredder is for the separation and recovery of smaller material and metal fractions. In this process, the large pieces of rolling stock material are milled and grinded into smaller pieces for further processing. These smaller prices of materials can then be sorted into different material fractions using magnetic properties and eddy current separators [14]. Consequently, the waste is segregated in ferrous metals (steel and irons), non-ferrous metals (Aluminum, zinc, copper, magnesium) and light shredder residue (a mixture of different substances and materials, for instance, fibers (textiles, wood), plastics (including foam and textiles), elastomers, glass and ceramics, residue (dust, paint coatings, rust) and remaining minerals (soil, sand). Ferrous and non-ferrous metals receive treatment to become recycled materials. Light shredder residue must be segregated for reuse or partly combusted for energy recovery, 
since it has a high calorific value. Around $50 \%$ of the light shredder residue contains a combustible portion that can be thermally treated. Although there are new technologies that enable sorting and using up to two-thirds of the mass of the shredder residue, in practice, approximately $67 \%$ of the remains, after the shredding process, are landfilled [20-24]. It is noted that the materials derived from shredding process cannot be classified as reusable. Some of the remains could be recycled depending on the material characteristic, properties, residual substance and composition and safety risks.

5. Treatment of separated and recovered materials

All the components and elements dismantled, except for those which are appropriate for direct reuse, are forwarded to specialized recycling facilities. Batteries, elements containing hazardous substances, operating fluids, electronics, parts for refurbishment, plastic and electric elements must receive dedicated recycling. In the same way, the materials segregated in the shredding process are forwarded to steelworks or non-ferrous metal recycling facilities. Some separated fractions of the shredder residue can be directly used in the industry, for example, fibers and foams can be utilised in sewage sludge conditioning and polymer granulate can be used in a blast furnace [1].

\subsection{Life Cycle of the Materials}

\subsubsection{Steel}

A life cycle assessment (LCA) of a steel product looks at energy, resources and emission, from the steel production stage to its end-of-life stage, including recycling. Without any significant loss of its inherent properties, steel could be recycled over and over again. Note that in some cases, quality loss of steel could be observed [22-29]. In general, the steel industry has many competitive advantages over other competing materials due to four keywords: reduce (over the past 50 years, steelmakers have, significantly, reduced the amount of energy required and raw materials to make steel. Furthermore, through investments in research and technology, the steel industry is developing the use of high-strength and advanced high-strength steel grades in many applications, in which less steel is needed to provide the same strength and functionality); reuse (due to its durability, steel can be reused with or without remanufacturing); remanufacture (many steel products can be remanufactured for reuse) and recycle (steel is $100 \%$ recyclable to create new steel products). Figure 6 illustrates the life cycle of steel [12].

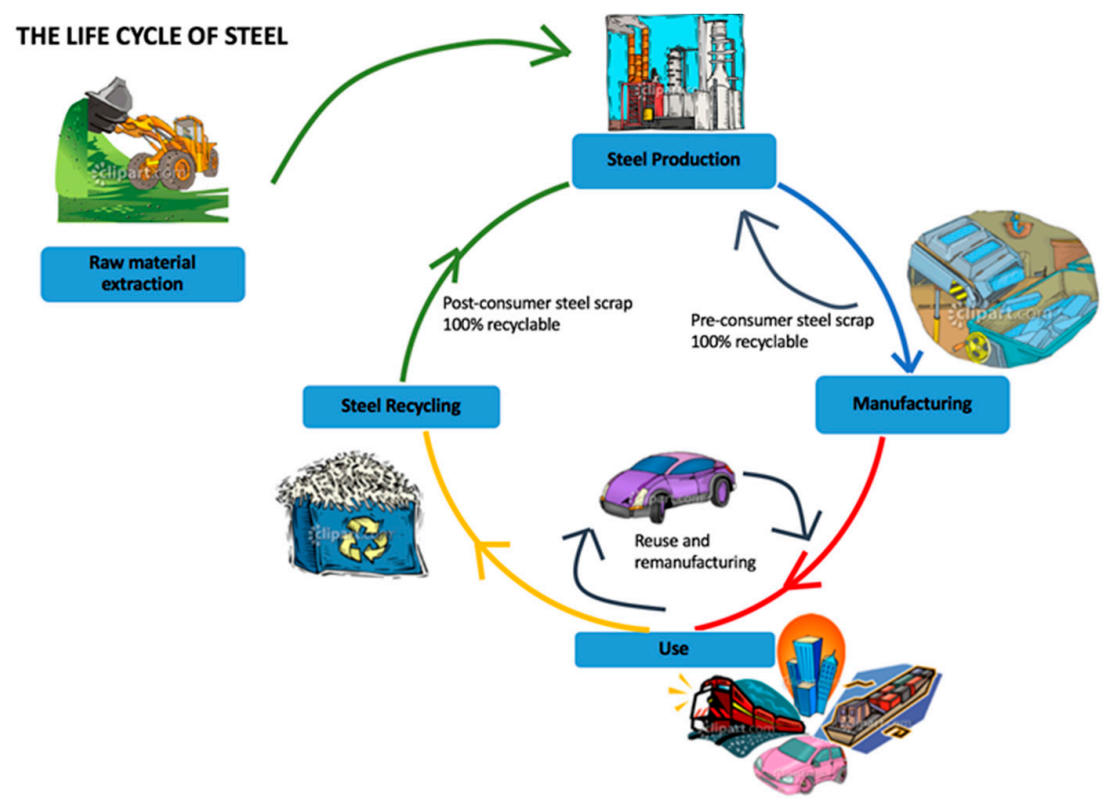

Figure 6. Life cycle of steel. 


\subsubsection{Aluminum}

The Aluminum industry generally manages three activities: initial processing and ore extraction, transformation into semi-products and, to finish off, the lifecycle of the finished goods, which can be fully recycled. Approximately $75 \%$ of all the Aluminum ever made is still in productive use [36,37]. Almost 100\% of Aluminum is infinitely recyclable as shown in Figure 7 [38,39].

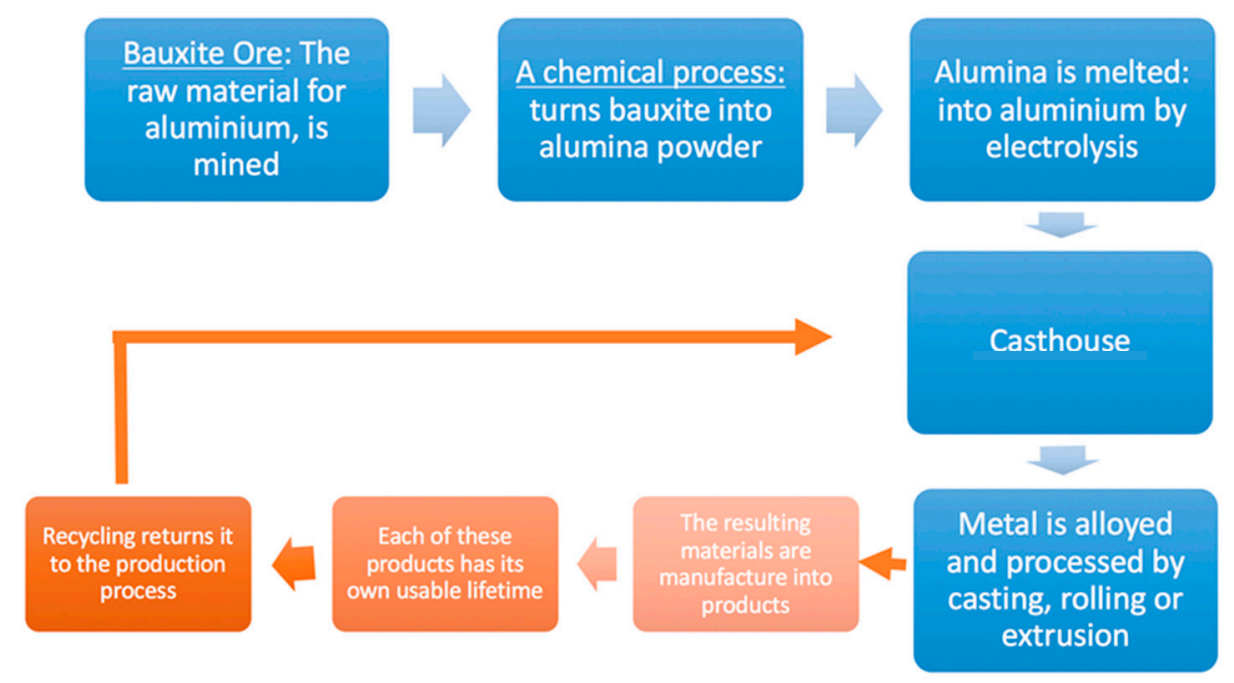

Figure 7. Life cycle of Aluminum.

\subsubsection{Plastic}

Although some plastics may be biodegradable or compostable, evidence indicates that this feature does not reduce waste [40-45]. Compostable plastics do not degrade in landfills either. Composting and biodegradation processes release carbon dioxide $\left(\mathrm{CO}_{2}\right)$ into the atmosphere. Note that plastics on trains are not biodegradable as they are required to safely reach their design life. Figure 8 illustrates the life cycle of plastics in general. The primary environmental impacts associated with plastic manufacturing are the Global Warming Potential, due to $\mathrm{CO}_{2}$ emissions from raw materials and Primary Energy Demand, for which the main contribution is the upstream production of energy, specifically, natural gas [44].

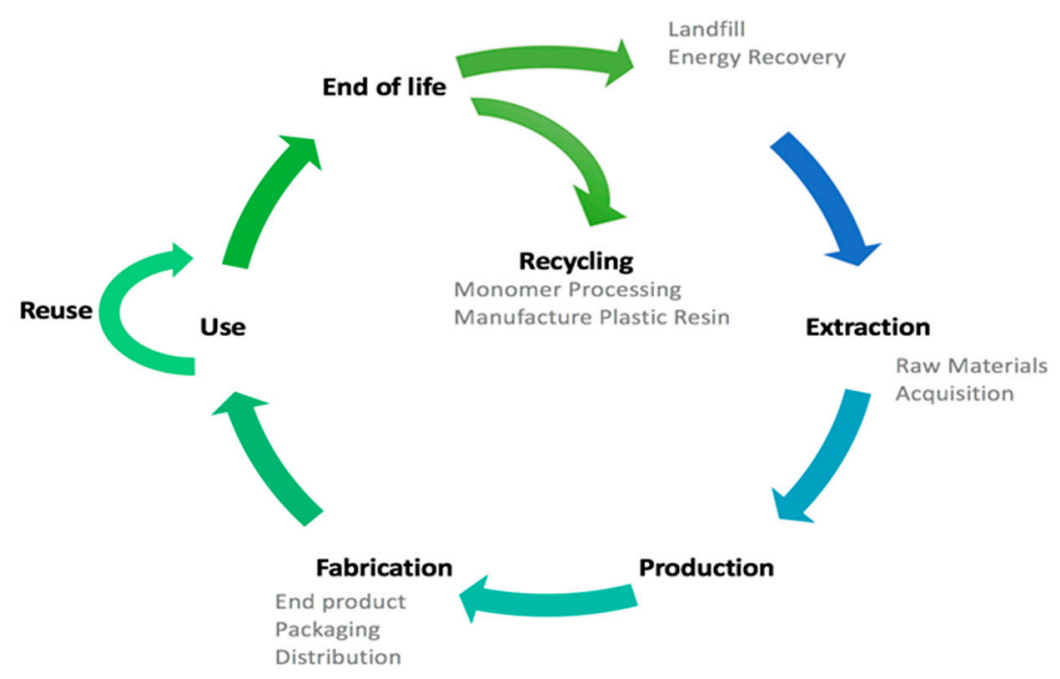

Figure 8. Life cycle of plastic. 


\subsubsection{Glass}

As shown in Figure 9, the life cycle of glass can be divided into 7 steps. Transportation of cullet and raw materials used in glass production represents less than 10 percent of the total energy utilized in the production of glass. The $\mathrm{CO}_{2}$ savings from glass recycling are larger than the transportation emissions [46-48].

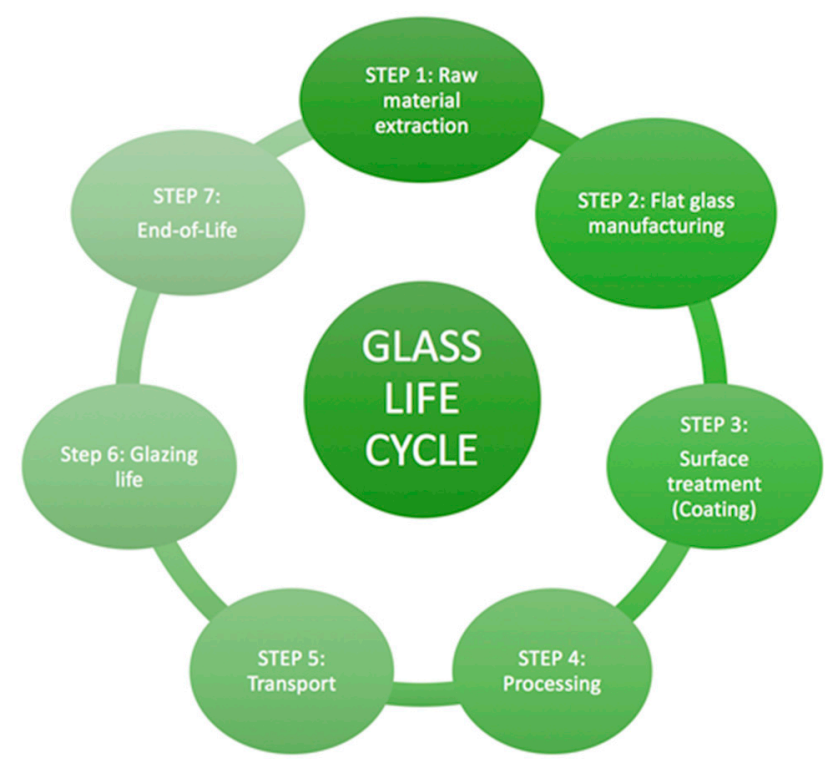

Figure 9. Life cycle of glass.

\subsection{Applications of the Rolling Stocks' Recycling}

As it has been recorded in the tables above, some rolling stock materials present a high recovery rate, which can be recycled and used in different applications. Reusing metal implies the reduction of $\mathrm{CO}_{2}$ emissions. One ton of reused metal displaces one ton of new metal of which its production demands much more significant energy and emits much more global warming gasses [8]. It is important to note that 'reuse' only has emission implications at the time of construction or manufacture. In this section, the applications of the main materials recycled from the trains [49-63] are discussed:

\subsubsection{Steel}

Steel is considered to be a recoverable material since it can be conveniently recovered by using the magnetic separation. Among the materials studied in this research, steel is the one with the highest recovery rate, between $90-98 \%$. Note that some losses of alloying elements can incur from shredding and contamination because their presence is rarely considered [20-22]. The steel production from the recovered material has low costs compared to the iron ores' production. It is an essential material used within railway industry. For instance, $20-25 \%$ of mass of passenger and high-speed trains are composed of steel. The bogies (the structure underneath the trains, such as wheels, bearings, axels and motors) are the main steel components. Freight trains are made totally of steel. Steel is also presently used in the railway track sleepers and fasteners, bridges, stations and overhead power lines (catenary poles). An example of reusable steel can be seen from the fact that its durability enables the steel rails to be reused by swapping over from the left to the right on the curved track. This practice was common in the past when curved-worn outer rail is replaced by inner rail. It can still be seen in third-class tracks around the world. When the steel rails are no longer suitable for main-line use, the rails can be tested for crack and then reutilized them again on secondary lines with lighter traffics. Recycling the steel at the end of its life results in a significant reduction in the energy cost associated 
with the material and the environmental impacts. After train components achieve the end of their life (around 40 years), almost all the steel will be recovered [9-12,20-28].

\subsubsection{Aluminum}

Currently, more than a half of all Aluminum produced in the European Union is originated from recycled raw materials. Similar to steel, Aluminum can be recycled without any loss of its properties. Recycling Aluminum considerably conserves energy and other natural resources. It saves more than $95 \%$ of the energy required for primary Aluminum production, then avoiding the emissions of greenhouse gases [36,37]. Recycled Aluminum can be used in several applications, such as computers, automobiles, siding, gutters, wire, boats, bicycles, cookware and many other products, which need a strong lightweight material, or a material with a high thermal conductivity. Global Aluminum recycling rates are generally high, for example: up to $60 \%$ for beverage cans and approximately $90 \%$ for construction applications and transport (mostly from rail sector). In this way, all the train components made of Aluminum can be reused after specific treatments. Furthermore, the recycling process is very economical since it uses less energy and recycling market is self-supported by commercial businesses due to the high value of used Aluminum [38].

\subsubsection{Plastic}

Different type of rolling stocks can comprise of various types of polymeric and plastic materials depending not only on the design and manufacture, but also on the modification and utilization of trains over the time. Recycling plastics can save economic resources, reduce greenhouse gas emissions, and minimize wastes to landfills. In general, terminology for plastic recycling is complex since there is a wide range of recovery and recycling activities. There are four recycling categories for plastics: primary (mechanical reprocessing into a product with equivalent properties, often referred to as "closed-loop recycling"), secondary (mechanical reprocessing into products that require lower properties, "downgrading"), tertiary (recovery of chemical constituents, applies when the polymer is de-polymerized to its chemical constituents, "chemical" or "feedstock recycling") and quaternary (recovery of energy, from waste or valorization) [9,39-43].

Closed-loop recycling is mostly used when the polymer constituent can be effectively separated from contamination sources or stabilized against deterioration during reprocessing or future reuse. In some cases, recovered plastics are used to make a new plastic product. This product can then displace all or a proportion of virgin polymer resin in primary recycling process. Some examples are plastic bins and crates manufactured from HDPE of milk bottles, and PET fiber from recovered PET packing (e.g., derived from polyester seats, tables or floors on a train, and so on). Secondary recycling happens when recovered plastic is put into an application that would not use virgin polymer, for example "plastic lumber" or "synthetic timber" (used in the trains such as in the office tables) as an alternative solution to the high cost and small lifetime of timber. In tertiary recycling, there is an advantage of recovering the petrochemical constituents of the polymer, which can be used to make other synthetic chemicals or to re-manufacture plastics. Chemical recycling of PET is considered more successful since de-polymerization under delicate conditions is possible. For example, glycolysis, hydrolysis or methanolysis can break down PET resin to make unsaturated polyester resins [39-43].

\subsubsection{Glass}

Recycling glass provides unmatched production efficiencies and considerable environmental benefits such as it lessens the demand for energy, cuts $\mathrm{CO}_{2}$ emissions, decreases the number of raw materials used, extends furnace life without any processing by-products and saves on overall manufacturing costs. Therefore, it is essential to recycle the glasses recovered from the trains in order to gain financial and environmental benefits [8,46-48]. If lamination or coating was applied to the glass, a mechanism to remove the film should be in place. Moreover, recycled glass is being used nowadays as aggregate in concrete. Based on its thermal properties of the glass aggregates, concrete made 
with recycled glass aggregates have shown better thermal insulation and better long-term strength. An ordinary application is the 'pipe bedding' located around sewer or water pipes to transfer weight from the surface and to protect the pipe. Other applications of recycled glass include: ceramic sanitary ware production, fiberglass insulation products, recycled glass countertops, abrasives, and agriculture and landscape applications, such as top dressing, root zone material or golf bunker sand [46].

\section{Discussion on the Potential of Rolling Stock Recycling}

Currently, there is a group of manufacturers (e.g., Bombardier, Alstom, Siemens, etc.) offering rolling stock vehicles that are fully designed to meet the needs for rolling stock recovery and recycling. For instance, Bombardier Transportation has adopted a resolution that all manufactured vehicles will aim at a $100 \%$ recovery rate. This will be possible by minimizing the utilization of hazardous materials and substances, by increasing the applications of recycling-friendly materials, such as Aluminum and steel, and avoiding excess number of materials [47-56].

As discussed earlier, there are a number of possible applications for the materials recycled from the rolling stocks (based on industry resources in References: [56-63]). During all recycling processes, the manufacturers should consider the costs needed and the quality of each material, in order to achieve the highest efficiency and benefit/cost ratio. By the same analogy, energy requirements, carbon emissions and environmental impacts also have to be analyzed throughout the whole life-cycle process. Firstly, steel has the recycling process that helps to save landfill space while it provides a valuable scrap resource for steel industry. Using recycled steel to make new products preserves energy and natural resources. For instance, for every ton of steel recycled, $635 \mathrm{~kg}$ of coal, $1134 \mathrm{~kg}$ of iron ore and $54 \mathrm{~kg}$ of limestone are conserved. Furthermore, the steel industry preserves correspondent energy to power around 18 million homes for 12 months [31,34,35].

Aluminum possesses the recycling process that enables cost savings over the production of new Aluminum and also conserves energy and natural resources. Recycling Aluminum needs around only $5 \%$ of the energy required to create Aluminum from bauxite [33]. It also reduces the uses of natural resources and chemicals (aluminum fluoride, caustic soda and lime) and eliminates the necessity for bauxite ore to be mined. In addition, it produces 95\% fewer greenhouse gas emissions (GHG) than manufacturing primary Aluminum. In terms of GHG saving, this is equivalent to taking 900,000 cars off the road during 12 months [30]. Also, 1 ton of Aluminum recycled avoids the emissions of around 9 tons of $\mathrm{CO}_{2}$ emissions [36-38].

For plastics, their recycling results in a reduction of oil consumption since manufacturers make plastics from crude oil derivatives or natural gas: 1 ton of recycled plastic saves 16.3 barrels of oil [34-38]. Therefore, it helps to save the remaining fossil fuel reserves. Moreover, 1 ton of recycled plastic saves the equivalent of 5,774 kilowatt-hours of electric energy. It also reduces the amount of waste: 1 ton of recycled plastic saves around $6.40 \mathrm{~m}$ of landfill space [39]. In addition, glass enables the recycling process that can also bring several significant environmental benefits. It broadly saves raw materials: for every 1 ton of recycled glass, over a ton of natural resources are conserved, such as $186 \mathrm{~kg}$ of soda ash, $590 \mathrm{~kg}$ of sand, $73 \mathrm{~kg}$ of feldspar and $173 \mathrm{~kg}$ of limestone [22,46-48]. As already mentioned, recycling glass lessens the demand for energy and cuts $\mathrm{CO}_{2}$ emissions: for every 6 tons of recycled glass used, a ton of carbon dioxide is reduced. Furthermore, since glass recycling is a closed-loop system, it does not create additional waste [53].

There are opportunities to improve vehicle design for rolling stock manufacturers. For instant, the design consideration should include the applications of recyclable materials, proper material assemblages (composites, bonding adhesive, etc.), ease for dissemble, retrofitability and material marking. These aspects in design play an important role at the end of life for rolling stocks because these rolling stocks may contain operational damages, biohazard materials, wear, tear and distortion during the life cycle. They could result in additional costs that discourage recycling of the rolling stock. The design considerations could be embraced by having a quicker dismantling and separation of the materials fractions. Based on our investigations, the combined recycling and recovery rate for rolling 
stock can potentially reach up to $95 \%$. This rate can be commonly found in motor vehicles. In fact, some train procurement contract has already included this rate in the selection criteria. However, it is always important to note that the actual recyclability and recovery rates will indeed depend on many local factors such as: accessibility to recovery technologies, demand for recycled materials and refurbished parts, new types of materials [64-68]. Regardless of the recoverability rate of the rolling stock, the recycling of rolling stocks cannot be successful without the technology enablers (such as train recycling business, material technologies, recycled material applications, and so on).

\section{Conclusions}

Despite the fact that there is neither legislation nor innovative procurement with respect to rail vehicle recycling, the European policy on waste management (e.g., Voluntary Policy of Union des Industries Ferroviaires Européennes or UNIFE) should be supported by rolling stock manufacturers, governments and its users: the public. Similarly, there should be no limitation to the scope of the applications of various disposal types (energy recovery, recycling). At present, modern vehicles are often prepared for their end-of-life recycling. Based on various recycling approaches, a wide range of materials can be re-processed and then secondary raw materials can be re-used. It is important that, when designing a vehicle, rolling stock manufacturers should embrace the necessity of recycling, which can be seen through the applications of recyclable materials, proper material assemblages, ease for dissemble, retrofitability and material marking. These approaches could occur in order to have a quicker dismantling and separation of the materials fractions. Based on our investigations, the combined recycling and recovery rate for rolling stock can potentially reach up to $95 \%$, which is similar to motor vehicles. The actual recyclability and recovery rates will depend on many factors such as: accessibility to recovery technologies, demand for recycled materials and refurbished parts, new types of materials. Moreover, it also depends on expectations and environment protection policies applied by the rolling stock owners and users, legal regulations to force business entities to achieve required recovery rates and the existence of infrastructure for specialized material recycling facilities. Finally, it is vital to embrace rolling stock recyclability in every modern rolling stock procurement contract to ascertain that sustainability and environmental values can be achieved at the end of life of the rolling stocks.

Acknowledgments: Valuable comments and discussions by ISO TC269 WG4 committee members and industry partners are gratefully acknowledged [4]. The authors would also like to thank British Department for Transport (DfT) for Transport-Technology Research Innovations Grant Scheme, Project No. RCS15/0233; and the BRIDGE Grant (provided by University of Birmingham and the University of Illinois at Urbana Champaign). The second author is gratefully acknowledges the Japan Society for the Promotion of Science (JSPS) for his JSPS Invitation Research Fellowship (Long-term), Grant No. L15701, at Track Dynamics Laboratory, Railway Technical Research Institute and at Concrete Laboratory, the University of Tokyo, Tokyo, Japan. The authors are sincerely grateful to European Commission for the financial sponsorship of the H2020-MSCA-RISE Project No. 691135 "RISEN: Rail Infrastructure Systems Engineering Network," which enables a global research network that tackles the grand challenge in railway infrastructure resilience and advanced sensing under extreme environment (www.risen2rail.eu) [69].

Author Contributions: Rafael Favoretto Silva and Sakdirat Kaewunruen conceived and designed the review framework; Rafael Favoretto Silva performed the critical review; Rafael Favoretto Silva analyzed the data; Sakdirat Kaewunruen contributed data/standards/analysis tools; everyone wrote the paper.

Conflicts of Interest: The authors declare no conflict of interest. The founding sponsors had no role in the design of the study; in the collection, analyses, or interpretation of data; in the writing of the manuscript, and in the decision to publish the results.

\section{References}

1. Merkisz-Guranowska, A.; Merkisz, J.; Jacyna, M.; Pyza, D.; Stawecka, H. Rail Vehicles Recycling. WIT Trans. Built Environ. Comput. Railw. XIV 2014, 135, 425-436. [CrossRef]

2. European Commission Environment. End of Life Vehicles. Available online: http://ec.europa.eu/ environment/waste/elv/ (accessed on 1 October 2016). 
3. Merkisz-Guranowska, A. Bicriteria Models of Vehicles Recycling Network Facility Location. Arch. Transp. 2012, 24, 187-202. [CrossRef]

4. International Standard Organisation. ISO TC269/WG4 Recyclability and Recoverability Calculation Method of Rolling Stock (draft); ISO: Geneva, Switzerland, 2016.

5. International Standard Organisation. ISO 22628: 2002 Road Vehicles-Recyclability and RecoverabilityCalculation Method; ISO: Geneva, Switzerland, 2012.

6. Del Pero, F.; Delogu, M.; Pierini, M.; Bonaffini, D. Life Cycle Assessment of a heavy metro train. J. Clean. Prod. 2015, 87, 787-799. [CrossRef]

7. Castella, P.S.; Blanc, I.; Ferrer, M.G.; Ecabert, B.; Wakeman, M.; Manson, J.A.; Emery, D.; Han, S.H.; Hong, J.; Jolliet, O. Integrating life cycle costs and environmental impacts of composite rail car-bodies for a Korean train. Int. J. Life Cycle Assess. 2009, 14, 429-442. [CrossRef]

8. Berzi, L.; Delogu, M.; Giorgetti, A.; Pierini, M. On-field investigation and process modelling of End-of-Life Vehicles treatment in the context of Italian craft-type Authorized Treatment Facilities. Waste Manag. 2003, 33, 892-906. [CrossRef] [PubMed]

9. Vermeulen, I.; Block, C.; Van Caneghem, J.; Dewulf, W.; Sikdar, S.K.; Vandecasteele, C. Sustainability assessment of industrial waste treatment processes: The case of automotive shredder residue. Res. Conserv. Recycl. 2012, 69, 17-28. [CrossRef]

10. Andrea Blengini, G.; Di Carlo, T. The changing role of life cycle phases, subsystems and materials in the LCA of low energy buildings. Energy Build. 2010, 42, 869-880. [CrossRef]

11. SSI Shredding Systems: Things you need to know about shredding. Available online: https://www.ssiworld. com/en/page/resources (accessed on 6 August 2016).

12. World Steel Association. Available online: https://www.worldsteel.org/steel-by-topic/life-cycleassessment/Life-cycle-thinking-in-the-circular-economy.html (accessed on 18 June 2016).

13. Matsuoka, S. Recyclability of stainless steel railway vehicles. Proc. Inst. Mech. Eng. Part F J. Rail Rapid Transit 2003, 217, 279-284. [CrossRef]

14. Delogu, M.; Del Pero, F.; Pierini, M.; Bonaffini, D. End-of-Life in the railway sector: Analysis of recyclability and recoverability for different vehicle case studies. Waste Manag. 2017, 60, 439-450. [CrossRef] [PubMed]

15. Elwert, T.; Goldmann, D.; Römer, F.; Buchert, M.; Merz, C.; Schueler, D.; Sutter, J. Current Developments and Challenges in the Recycling of Key Components of (Hybrid) Electric Vehicles. Recycling 2015, 1, 25-60. [CrossRef]

16. Ito, M.; Nagai, K. Degradation behavior and application of recycled PVC sheet made of floor sheet for railway vehicle. Polym. Degrad. Stab. 2007, 92, 1692-1699. [CrossRef]

17. Berzi, L.; Delogu, M.; Pierini, M.; Romoli, F. Evaluation of the end-of-life performance of a hybrid scooter with the application of recyclability and recoverability assessment methods. Res. Conserv. Recycl. 2016, 108, 140-155. [CrossRef]

18. Bartl, A. Moving from recycling to waste prevention: A review of barriers and enables. Waste Manag. Res. 2014, 32, 3-18. [CrossRef] [PubMed]

19. Miller, L.; Soulliere, K.; Sawyer-Beaulieu, S.; Tseng, S.; Tam, E. Challenges and Alternatives to Plastics Recycling in the Automotive Sector. Materials 2014, 7, 5883-5902. [CrossRef]

20. Ohno, H.; Matsubae, K.; Nakajima, K.; Kondo, Y.; Nakamura, S.; Nagasaka, T. Toward the efficient recycling of alloying elements from the end of life vehicle steel scrap. Res. Conserv. Recycl. 2015, 100, 11-20. [CrossRef]

21. Ohno, H.; Matsubae, K.; Nakajima, K.; Nakamura, S.; Nagasaka, T. Unintentional Flow of Alloying Elements in Steel during Recycling of End-of-Life Vehicles. J. Ind. Ecol. 2014, 18, 242-253. [CrossRef]

22. Ohno, H.; Nuss, P.; Chen, W.-Q.; Graedel, T.E. Deriving the Metal and Alloy Networks of Modern Technology. Environ. Sci. Technol. 2016, 50, 4082-4090. [CrossRef] [PubMed]

23. Steel Construction. 'Recycling and Reuse'. Available online: http://www.steelconstruction.info/Recycling and_reuse (accessed on 25 July 2016).

24. World Steel Association. Case Study: High-Speed Rail Networks: A Sustainable Steel Solution; WSA: Brussels, Belgium, 2016; Volume 1.

25. Bowyer, J.; Bratkovich, S.; Fernholz, K.; Frank, M.; Groot, H.; Howe, J.; Pepke, E. Understanding Steel Recovery and Recycling Rates and Limitations to Recycling; Dovetail Partners Inc.: Minneapolis, MN, USA, 2015; pp. 1-12.

26. Tata Steel. Global Steel Company Pioneering in Steel Manufacturing; Tata Steel: Mumbai, India, 2016. 
27. Allwood, J.M.; Cullen, J. M.; Cooper, D.R.; Milford, R.L.; Patel, A.C.H.; Carruth, M.A.; McBrien, M. Conserving Our Metal Energy; University of Cambridge: Cambridge, UK, 2010; Volume 1, pp. 1-17.

28. Steel Recycling Institute. Available online: http://www.recycle-steel.org/steel-markets/cans.aspx (accessed on 15 June 2016).

29. United Nation Environmental Programme. Metal Recycling: Opportunities, Limits, Infrastructure; A Report of the Working Group on the Global Metal Flows to the Inter-national Resource Panel; UNEP: Nairobi, Kenya, 2013.

30. The Aluminum Association. Aluminum: The Element of Sustainability: A North American Aluminum Industry. Available online: http:/ /www.aluminum.org/sites/default/files/Aluminum_The_Element_of_ Sustainability.pdf (accessed on 15 June 2016).

31. Novelis Recycling UK: No Other Material Offers the Versatility and Environmental Benefits of Aluminum. Available online: http://www.novelisrecycling.co.uk/novelis-recycling/why-recycleAluminum/ (accessed on 15 June 2016).

32. Yang's Research. High-Speed Train-Tunnel Interactions. Available online: http://www.ms.t.kanazawa-u.ac. jp/ fluid/staff/yang/train.html (accessed on 6 August 2016).

33. TGVweb-TGV Dimensions. Available online: http://www.railfaneurope.net/tgv/dimensions.html (accessed on 29 June 2016).

34. Popular Mechanics: Freight Train. Available online: http://www.popularmechanics.com/technology/ infrastructure/a5314/4345689/ (accessed on 2 July 2016).

35. Rolling Stock Manufacturing. Available online: http://www.railway-technical.com/Manufacturing.shtml (accessed on 29 June 2016).

36. Cossu, R.; Fiore, S.; Lai, T.; Luciano, A.; Mancini, G.; Ruffino, B.; Viotti, P.; Zanetti, M.C. Review of Italian experience on automotive shredder residue characterization and management. Waste Manag. Ind. Waste 2014, 34, 1752-1762. [CrossRef] [PubMed]

37. Azo Materials. Aluminum and Aluminum Alloys—Life Cycle of Aluminum; Azom: West Bengal, India, 2006; Volume 1.

38. Ciacci, L.; Chen, W.; Passarini, F.; Eckelman, M.; Vassura, I.; Morselli, L. Historical evolution of anthropogenic aluminum stocks and flows in Italy. Res. Conserv. Recycl. 2013, 72, 1-8. [CrossRef]

39. Buekens, A.; Zhou, X. Recycling plastics from automotive shredder residues: A review. J. Mater. Cycles Waste Manag. 2014, 16, 398-414. [CrossRef]

40. Life Cycle Assessment for a Plastic and a Glass Product. Available online: https://lifecycleofplastic. wordpress.com (accessed on 2 August 2016).

41. Hopewell, J.; Dvorak, R.; Kosior, E. Plastics recycling: Challenges and opportunities. Philos. Trans. R. Soc. B Biol. Sci. 2009, 364, 2115-2126. [CrossRef] [PubMed]

42. Home Guides: Benefits and Savings of Recycling Plastic. Available online: http://homeguides.sfgate.com/ benefits-savings-recycling-plastic-79284.html (accessed on 15 June 2016).

43. Complete Recycling: Plastic Recycling Facts. Available online: https://www.completerecycling.com/ resources/plastic-recycling (accessed on 15 June 2016).

44. Fukumori, K.; Matsushita, M. Material recycling technology of crosslinked rubber waste. R D436 Rev. Toyota CRDL 2003, 38, 39-47.

45. Kaewunruen, S.; Lopes, L.M.P.C.; Papaelias, M.P. Influences of Sleeper/Crosstie Material Choices on Georisks in Railway Systems under Climate Uncertainties; Jordan University of Science and Technology: Dead Sea, Jordan, 2017; pp. 1-10.

46. Poutos, K.H.; Alani, A.M.; Walden, P.J.; Sangha, C.M. Relative temperature changes within concrete made with recycled glass aggregate. Constr. Build. Mater. 2008, 22, 557-565. [CrossRef]

47. Reimann, K. Environmental Product Declarations at Bombardier Transportation. Bombard. Transp. 2012, 1, 1-17.

48. Glass Packaging Institute: Recycling. Available online: http://www.gpi.org/recycling/why-recycle-glass (accessed on 15 June 2016).

49. The Railway Technical Website, Bogie Parts \& Description. Available online: http://www.railway-technical. com/ (accessed on 6 July 2016).

50. Constellium: Life cycle of Aluminum. Available online: http://www.constellium.com/sustainability/lifecycle-of-Aluminum (accessed on 18 June 2016). 
51. De Vimal, X. Technical Memorandum Pantograph Clearance Envelopes. Available online: http://www. tillier.net/stuff/hsr/TM-3.2.3-Pantograph-Clearance-Envelopes-R0-090717.pdf (accessed on 6 July 2016).

52. First Class Bogies. Siemens. Available online: http://www.mobility.siemens.com/mobility/global/ sitecollectiondocuments/en/rail-solutions/components-and-systems/bogies-catalog-en.pdf (accessed on 26 July 2016).

53. Hamada, K.; Hino, S.; Miura, N.; Watanabe, H.; Nakata, S.; Suekawa, E.; Ebiike, Y.; Imaizumi, M.; Umezaki, I.; Yamakawa, S. $3.3 \mathrm{kV} / 1500$ Power modules for the world's first all-SiC traction inverter. Jpn. J. Appl. Phys. 2015, 54, 4-7. [CrossRef]

54. High Speed Train Links Page. Available online: http://www.railway-technical.com/hst-01.shtml (accessed on 29 June 2016).

55. HubPages: The Japanese High Speed Train (Current Model). Available online: http://hubpages.com/ politics/High-Speed-Rail-Its-History-and-Implications-in-North-America (accessed on 29 June 2016).

56. NW-100-CN Passenger Car Air Conditioning Condenser. Available online: http://www.nwrail.com/nwre products/100cn.html (accessed on 15 July 2016).

57. Our Environmental Commitments. Available online: http://scandinavia.saint-gobain-glass.com/ environment/glass-life-cycle.htm (accessed on 15 July 2016).

58. Stead Resistors-Wirewound Resistors, Rheostats, Potentiometers, Heating Resistors. Available online: http:/ / www.steadresistors.com/products/dynamic-breaking-resistors.htm (accessed on 20 July 2016).

59. TGVweb—“Under the Hood” of a TGV. Available online: http://www.railfaneurope.net/tgv/motrice.html (accessed on 29 June 2016).

60. Traction Transformers. Available online: http://www.alstom.com/products-services/product-catalogue/ rail-systems/components/traction-transformers / (accessed on 29 June 2016).

61. Wikipedia: External Part of a Passenger Train. Available online: https://en.wikipedia.org/wiki/Train\# Passenger_trains (accessed on 20 July 2016).

62. Wikipedia: Interior of a Passenger Train. Available online: https://en.wikipedia.org/wiki/Passenger_car_ (rail) (accessed on 20 July 2016).

63. Wired: High Speed Rail. Available online: http://www.wired.com/2010/04/the-trouble-with-high-speedrail/ (accessed on 29 June 2016).

64. Chester, M.V.; Horvath, A. Environmental assessment of passenger transportation should include infrastructure and supply chains. Environ. Res. Lett. 2009, 4, 237-266. [CrossRef]

65. Chester, M.V.; Horvath, A. Life-cycle assessment of high-speed rail: The case of California. Environ. Res. Lett. 2010, 5, 123-129. [CrossRef]

66. Boughton, B.; Horvath, A. Environmental assessment of shredder residue management. Res. Conserv. Recycl. 2006, 47, 1-25. [CrossRef]

67. Kaewunruen, S.; Lee, C.K. Sustainability Challenges in Managing End-of-Life Rolling Stocks. Front. Built Environ. 2017, 3. [CrossRef]

68. Setsobhonkul, S.; Kaewunruen, S.; Sussman, J.M. Lifecycle assessments of railway bridge transitions exposed to extreme climate events. Front. Built Environ. 2017, 13, 331-344. [CrossRef]

69. Kaewunruen, S.; Sussman, J.M.; Matsumoto, A. Grand Challenges in Transportation and Transit Systems. Front. Built Environ. 2016, 2, 4. [CrossRef]

(C) 2017 by the authors. Licensee MDPI, Basel, Switzerland. This article is an open access article distributed under the terms and conditions of the Creative Commons Attribution (CC BY) license (http:// creativecommons.org/licenses/by/4.0/). 